
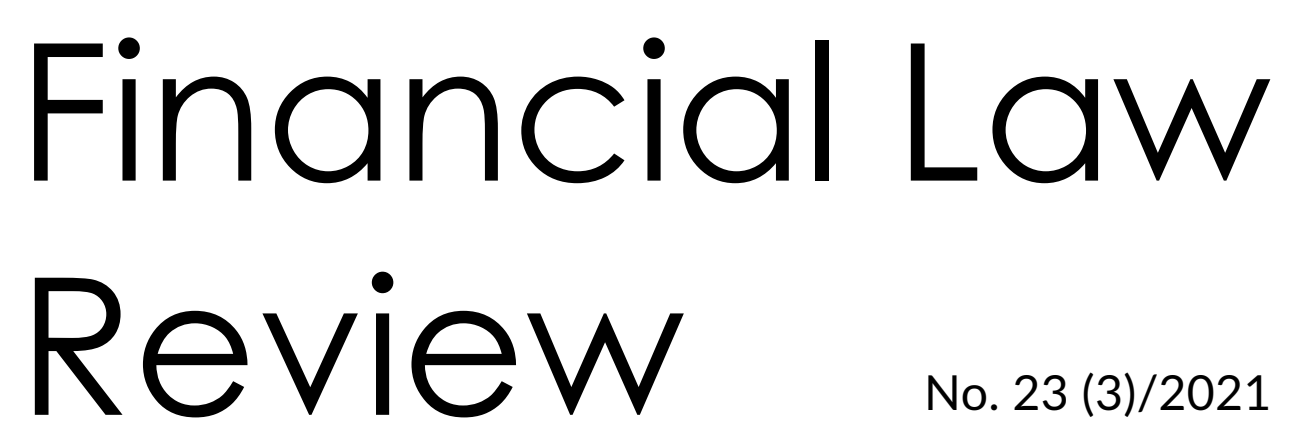

No. $23(3) / 2021$

UNIVERSITY OF GDAŃSK • MASARYK UNIVERSITY • PAVEL JOZEF ŠAFÁRIK UNIVERSITY • UNIVERSITY OF VORONEZH http://www.ejournals.eu/FLR

\title{
EWA DERC*
}

\section{LEGAL STATUS OF THE FINANCIAL OMBUDSMAN IN THE EUROPEAN UNION - RISKS AND CHALLENGES}

\begin{abstract}
This contribution deals with the protection of consumer rights which must be clear and certain. At the same time, it is not possible to protect the important interests of the stability of the financial market and its actors and, at the same time, to protect those who use the services of these actors. After all, the interests of the parties in a contract are not entirely compatible, the client wants to receive the lowest possible price of capital and the borrower the highest possible price. A body that will protect one party will not be independent with regard to the other interest being protected. The idea of all the Financial Ombudsmen created after 2008 is precisely that of protecting one party, the consumer/customer, who, in his or her own way, is the guarantor of the banks' liquidity security. This idea prevails where the consumer of financial services is effectively protected. The Ombudsman is, in a way, a consequence, but also a guarantor of financial stability and the financing system, and not speculation on consumers.
\end{abstract}

Key words: financial law, law, Financial Ombudsman.

JEL Classification: K34

\footnotetext{
* Attorney at law, PhD Student, University of Gdańsk.

Contact email: derc@dercpalka.pl, https://orcid.org/0000-0002-7547-3326.
} 


\section{Introduction}

The institution of the Financial Ombudsman is not a newcomer to the European and global market for ever-growing financial services. Such institutions operate in many countries of the European Union, but also on other continents, where legal protection for clients of financial institutions is developed, such as the United States. The dynamics of development of these services, the emergence of new entities dealing with the latest technologies and the growing trend in consumer protection require that this phenomenon be dedicated to a single, strong body dealing with the financial market in an exclusive manner. The establishment of the institution of the Financial Ombudsman in many countries is accompanied by many changing social, economic or institutional conditions. The ombudsmen fill different areas of competence, not only as alternative dispute resolution entities, but also, and above all, as independent assessors of the functioning of financial services for clients and consumers and, in some countries, even investors [Thomas, Frizon 2012: 4].

In recent years, the institutions responsible for protecting consumer interests in the European Union Member States have been observing the impact of complaints relating to infringements of consumer rights, a significant part of the total number of notifications and signals received annually by such bodies. Therefore, especially in crisis situations, effective, prompt and targeted intervention to prevent and remedy existing consumer rights violations is crucial for trade safety and building citizens' trust in the state.

Effective and efficient consumer protection is particularly important for the functioning of the financial services market, which is a market with increased risk for consumers. The products offered on the market are often characterized not only by a high level of complexity, but also their purchase entails long-term financial obligations (e.g. credits, insurance), having a significant impact on the functioning of both individual consumers and entire households. For example, in the last few years, we can observe an increase in the problem of the so-called "misselling", example: the sale of products not adjusted to consumer needs. It concerns to the greatest extent certain financial products whose complexity (natural or purposeful) excludes the possibility of assessing their suitability by a typical consumer.

Therefore, the reasonable expectation of clients of financial market entities is to be able to obtain quick help in cases of observed violations of law. It is important to obtain free of charge legal assistance and information, and in particular to take action by state authorities. 


\section{Legal status of the consumer rights protection system in Poland}

In the current legal status, the consumer rights protection system in Poland is dichotomous. They operate on it in parallel:

1) entities acting in the interest of consumers in general (collective consumer interests), such as the Financial Supervision Authority (Komisja Nadzoru Finansowego - "KNF") and the Office of Competition and Consumer Protection (Urząd Ochrony Konkurencji i Konsumentów - "UOKiK"), and

2) entities whose purpose is to act in the protection of individual consumer rights - the Financial Ombudsman and district and municipal consumer advocates.

A significant part of the competencies remaining within the competence of the President of the Office of Competition and Consumer Protection (the President of the Office or the President of the Office of Competition and Consumer Protection) remains simultaneously within the competence of the Financial Ombudsman [Act on the handling of complaints by financial market entities and on the Financial Ombudsman, art. 25]. These include, among others:

1. the possibility of submitting an important opinion on the case,

2. giving opinions on draft legal acts concerning the organization and functioning of financial market entities,

3. inform the competent supervisory and control authorities of detected irregularities in the functioning of financial market operators,

4. requesting information or explanations, files and documents from financial market entities and other entities whose activities are related to the case under consideration,

5. carrying out or commissioning a study on the situation on the financial market, in particular to protect the interests of the clients of the entities of this market [Act on Competition and Consumer Protection, art. 31].

Today, the protection of consumer rights must be clear and certain. At the same time, it is not possible to protect the important interests of the stability of the financial market and its actors and, at the same time, to protect those who use the services of these actors. After all, the interests of the parties in a contract are not entirely compatible, the client wants to receive the lowest possible price of capital and the borrower the highest possible price. A body that will protect one party will not be independent with regard to the other interest being protected. The idea of all the Financial Ombudsmen created after 2008 is precisely that of protecting one party, the consumer/customer, who, in his or her own way, 
is the guarantor of the banks' liquidity security. This idea prevails where the consumer of financial services is effectively protected. The Ombudsman is, in a way, a consequence, but also a guarantor of financial stability and the financing system, and not speculation on consumers [Horbova, Volodymyr, Basysta, Riabchynska, Hayrapetyan 2019: 1].

\section{Sources of the European Union law setting standard for the functioning of the Financial Ombudsmen}

In order to identify the sources of European Union law that set the standard for the functioning of the Financial Ombudsmen, reference should be made primarily to the following European Union acts:

(1) Directive 2013/91/EU of the European Parliament and of the Council of 21 May 2013 on alternative dispute resolution for consumer disputes and amending Regulation (EC) No 2006/2004 and Directive 2009/22/EC (Directive on consumer ADR), hereinafter referred to as the "ADR Directive" [Directive 2013/91/EU of the European Parliament and of the Council of 21 May 2013 on alternative dispute resolution for consumer disputes and amending Regulation (EC) No 2006/2004 and Directive 2009/22/EC, art. 1];

(2) Regulation (EU) 2017/2394 of the European Parliament and of the Council of 12 December 2017 on cooperation between national authorities (AZORITI) responsible for the enforcement of consumer protection laws and repealing Regulation (EC) No 2006/2004, hereinafter referred to as CPC [Regulation (EU) 2017/2394 of the European Parliament and of the Council of 12 December 2017 on cooperation between national authorities (AZORITI) responsible for the enforcement of consumer protection laws and repealing Regulation (EC) No 2006/2004, art. 1].

In accordance with the ADR Directive, States should ensure that ADR bodies (i) are independent, impartial and not subject to instructions from either party or their representatives, (ii) are appointed for a term of office sufficient to ensure the independence of their actions and should not be relieved of their obligations without good cause, and (iii) have the necessary expertise in alternative or judicial resolution of consumer disputes. (Recital 32 of the Directive). The independence of ADR entities is essential in order to build the confidence of Union citizens in ADR mechanisms and to convince them that they ensure a fair and independent outcome. The natural person or collegiate body responsible for ADR should be independent of all persons and entities which may have an interest in the outcome of the procedure and should not be involved in any conflict of interest that may hinder a fair, impartial and independent decision. 
The aim of the ADR Directive is - to achieve a high level of consumer protection - to contribute to the proper functioning of the internal market by ensuring that consumers can voluntarily complain about traders' actions to entities offering independent, impartial, transparent, focused, prompt and fair alternative dispute resolution. Under the CPC Regulation (Article 9 and recitals 6 and 7), it is possible to grant minimum competences to one or more consumer protection competent authorities and to delegate certain activities to other entities [Gill, Williams, Brennan, Hirst 2014: 1].

Pursuant to the provision of Article 5(2) of the CPC Regulation, the following attributes can be listed which, in the opinion of the authors of the CPC Regulation, should be the characteristics of the competent authority: (i) action by the competent authority on its own behalf (abbreviated subjective and qualitative Polish version), (ii) action by the competent authority in the interest of consumers of its own Member State and on its own behalf. The criterion for a competent authority to act on its own behalf can only be met by an entity having legal personality. The CPC Regulation uses the term "acting on behalf of" to refer to the relevant conceptual framework of substantive civil law. If the Financial Ombudsman does not have a separate legal entity from the State Treasury, he cannot fulfil the function of the competent authority. The existence of the Financial Ombudsman, as an independent institution acting for the benefit of consumers, is, in fact, essential in view of the obligations of the Polish State under EU law and the rich body of case-law of the CJEU, including Directive $93 / 13$ on unfair terms in consumer contracts.

\section{Models of the Financial Ombudsman}

The world practice mainly identifies two models of the functioning of the institution of Financial Ombudsman: German and British. Therefore, it is important to consider the features of each of them. Thus, the emergence of the first out-of-court procedure for settling disputes between banks and customers with the participation of the financial ombudsman took place in 1992 in Germany on the initiative of the Association of German Public Banks. It should be noted that in Germany there is no specialized regulatory framework for regulating the activities of the financial ombudsman. Therefore, such activities are carried out in compliance with the regulations developed by the Association of German Public Banks. In the UK, the institution of ombudsman provides for an independent public institution funded by public funds; that is the difference from the German model. A characteristic feature of the institution of financial ombudsman in this 
country is that it is created at the initiative of the state and carries out its activities in accordance with the requirements of the Financial Services Act (2012) [Noked 2013: 1].

It is important to emphasize that the right to use the services of the British financial ombudsman is given not only to individuals, but also to legal entities. The Ombudsman's attribute is his independence. This is a guarantee of effectiveness. He who protects the rights of the weak must be independent. This is the benchmark of the French ACPR. In France, the Prudential Control Authority (ACPR) supervises banks and insurance companies. The ACPR is an administrative body whose French monetary and financial code establishes independence in the performance of its tasks and financial independence. It was created on 9 March 2010 by a regulation of 21 January 2010. ACP as a response to the financial crisis is the result of a merger of the banking and insurance sector supervisory authorities. It is a whole administrative apparatus with an office, directorates and secretariat-general [Bussière, Camara, Castellani, Potier, Schmidt 2014: 1].

In Canada, the Banking and Investment Ombudsman (OBSI) is a Canadian, national, independent non-profit institution. It offers free dispute resolution services for financial products and services offered by banks or investment firms. The services are provided free of charge to consumers as they are financially supported by industry contributions from entities supervised in accordance with the requirements of the regional securities regulators and the federal banking supervision authorities. OBSI also has to comply with specific rules to maintain its non-legitimacy. For example, the Board of Directors of OBSI, consists mainly of non-industry and non-government related directors and an independent chairman [Khoury 2011: 84-88].

Irrespective of the examples given, the FIN-NET network, the pan-European network of financial ombudsmen and organisations dealing with consumer complaints, should be mentioned. FIN-NET was set up by the European Commission in 2001. Its objectives are:

- promoting cooperation between national financial ombudsmen;

- ensuring that consumers have easy access to alternative problem-solving methods (ADR) for cross-border disputes concerning the provision of financial services [Mania 2010: 81].

\section{Ideas to liquidate the Financial Ombudsman in Poland}

Possible ideas to liquidate the Financial Ombudsman in each of the European Union countries (e.g. in view of the idea and draft law presented in Poland to liquidate the 
Financial Ombudsman and replace him with the function of coordinator in the structure of the Office for Competition and Consumer Protection, whose President, in addition, may at any time (unlike in the case of the Financial Ombudsman) be dismissed by decision of the President of the Council of Ministers, in the absence of clear provisions of secondary European Union law which would regulate the functioning of Financial Ombudsmen in the European Union and guarantee their independence, may lead to consumers being deprived of protection in the financial services market. The lack of specialisation in the financial services market in the area of supervisory bodies and control over the financial market, as history shows, leads to violations in this market, and consumers and financial institutions lose out. Finally, it should be pointed out that the process of winding up the Financial Ombudsman is also contrary to the direction set by the European Commission itself, that is to say, the creation in 2001. The European Network of Financial Ombudsmen, FIN-NET, and the autonomy of the European Ombudsmen in financial services in 2001 [Stone 2001: 1].

As for the Polish example, the Advisory Scientific Committee beside the Polish Financial Ombudsman, in view of the information emerging in the public space about the intention to liquidate the institution of the Financial Ombudsman and take over his functions by the President of the Office for Competition and Consumer Protection, has publicly expressed its opinion on this issue [Financial Ombudsman, Position of the Advisory Scientific Committee to the Financial Ombudsman in view of the information appearing in the public domain about the intention to liquidate the institution of the Financial Ombudsman and taking over its functions by the President of the Office of Competition and Consumer Protection].

The Committee took the position that liquidation of the institution of the Financial Ombudsman:

1. is in contradiction with the new canon of consumer policy, developed on the basis of international experience from the recent global financial crisis (2007-2009), which states that all issues related to the protection of consumer rights with exceptional characteristics should be entrusted to highly specialised bodies, separate from those responsible for the general consumer protection system. Such a feature of uniqueness (complexity, individual and social importance, susceptibility to pathologies) are issues related to the protection of consumer rights of financial services. It is a result of immateriality and heterogeneity of financial services, high dynamics of innovation of these services, their digitalization, steadily increasing speed of their provision combined with long duration and often very 
negative effects of their purchase by the client or finally integration of European financial market.

Effective consumer protection of financial services requires the use of a very wide range of know-how gathered in one body. This has been recognised by governments in many countries around the world. According to a World Bank study (2014) on a sample of 114 countries, the Office of the Ombudsman was present in 69 of them.

Liquidation of the institution of the Ombudsman would, on the one hand, drastically reduce the level of consumer protection of financial services using the "field", nonprofessional financial market infrastructure at the disposal of the Office of the Ombudsman (district and municipal ombudsmen for all consumers), and, on the other hand, would lead to a waste of know-how accumulated over the years in the Office of the Ombudsman that cannot be overestimated. The reduction in the level of consumer protection of financial services would take place in a period of crisis caused by the pandemic, which would encourage the emergence of aggressive sales practices of financial institutions, which deliberately use social engineering techniques.

2. It contradicts the current doctrine that the public interest and the individual interest are two separate institutions and that the public interest is not the sum of individual interests. This doctrine underlies the personal separation of bodies carrying out public law tasks related to the protection of the collective interests of consumers and bodys/entities dealing with the recovery of individual customer claims. The activities of the President of the Office of Competition and Consumer Protection (UOKiK) are focused on the protection of the collective interests of customers, and the activities of the Financial Ombudsman are focused on the interests of individual consumers who have suffered damage. In the case of liquidation of the independent office of the Financial Ombudsman, there will be a risk of disruption of activities for the benefit of individual consumer interests, remaining in high synergy with the risk of exceeding the powers and failing to meet the obligations of public officers obliged to supervise capital markets, competition and consumer protection, which materialized in the case of the largest financial scandals in Poland after 1989, the Amber Gold scandal, the GetBack scandal and the capital fund insurance scandal [Financial Ombudsman, Position of the Advisory Scientific Committee to the Financial Ombudsman in view of the information appearing in the public domain about the intention to liquidate the institution of the Financial Ombudsman and taking over its functions by the President of the Office Office of Competition and Consumer Protection]. 
3. It leads to the loss of a very strong point of the functioning model of financial services consumer protection, consisting in the fact that the Ombudsman supports consumers at every stage of a dispute with a service provider - a financial institution, starting with counseling, conducting intervention and amicable proceedings, and ending with issuing socalled "essential views" on the case at the stage of court proceedings. An important competence of the Ombudsman is the possibility of out-of-court proceedings to resolve disputes between clients and service providers - he is an entity authorized under the Community ADR system (Alternative Dispute Resolution), entered in the register kept by the President of the Office of Competition and Consumer Protection on the basis of the Act on out-of-court resolution of consumer disputes. It is impossible for the President of Office to take over this competence at the moment of liquidation of the Office of the Ombudsman. In a situation where the President of Office is the registration and monitoring body for the arbitration activity, this would mean that we are facing to conflict of interest.

4. It means resignation from a specific and very important system fuse, which consists in the fact that the Ombudsman realizes a specific compliance with the financial market supervision system. The independent office, which signals possible directions of actions to the supervisor, will disappear.

The Committee has requested the Ministry of Finance to urgently undertake legislative work to strengthen the institution of the Financial Ombudsman in the Polish legal system, and to urgently undertake legislative work to eliminate a significant legal defect in the functioning of the Financial Education Fund and to introduce a substantive correction consisting in taking into account the fact that individual consumers and consumer organizations are the key stakeholders of the financial education system when forming the Financial Education Council.

One should take the position that the liquidation of the institution of the Financial Ombudsman cannot be supported, due to, among other things, the fact that it is in contradiction with the prevailing in the European Union and in the world an institutional model of consumer protection. It should be pointed out that in Europe (not only in the EU), the model of sub-authority separation of bodies carrying out public law tasks related to the implementation of consumer protection policy (protection of the collective interests of consumers) and bodies/authorities dealing with individual customer claims and amicable settlement of disputes is definitely dominant. In the world, the task of protecting the collective interests of consumers is most often carried out by institutions within the government structure. These are ministries, their bodies set up to achieve these goals or institutions under the direct authority of the Prime Minister, but also independent public 
institutions. Support for individual consumers is provided by non-governmental consumer organizations and out-of-court consumer dispute resolution bodies or independent public institutions (Germany, Sweden, the Netherlands, Denmark, France, Norway, Italy, Portugal, USA, United Kingdom, Canada, Ireland, India).

In accordance with Article 17 of the Act of 5 August 2015 on the processing of complaints by financial market entities and on the Financial Ombudsman, the tasks of the Ombudsman include taking action to protect the clients of financial market entities whose interests he represents. It should be pointed out with conviction that the above mentioned standard of protection of clients of financial market institutions - in case of liquidation of the Financial Ombudsman - will deteriorate. It should be pointed out that the actions taken so far by the Ombudsman in the field of individual protection of financial market clients have proved the need for this institution to exist.

\section{Activity of the Financial Ombudsman in Poland}

In Poland in 2019. The Ombudsman intervened individually against financial market entities in 15.3 thousand cases out of 18.4 thousand requests for intervention (in 2018 15.6 thousand cases). The client received a positive outcome in 2.8 thousand cases, i.e. $25 \%$ (in 20182.3 thousand cases, i.e. 22.2\%) out of a total of 11.2 thousand intervention cases completed in 2019. (in 201810.7 thousand cases). In the amicable (ADR) proceedings, in 2019 the Ombudsman received 2.7 thousand motions for out-of-court dispute resolution, out of which 369 cases (13.7\%) ended amicably. As a result of settlements and agreements concluded, clients, without the need to conduct court proceedings, received a total of PLN 3.7 million, i.e. 44\% of the total amount of PLN 8.4 million in claims filed (in 2018 PLN 3.3 million of the PLN 5.8 million in claims filed). In court proceedings, the Ombudsman presented to the courts in 2019.1069 of the so-called significant views in the case (vs. 552 in 2018).

In addition, the Financial Ombudsman actively participated in the ongoing proceedings or initiated them himself, among other things, he presented opinions in cases requiring resolution by the Supreme Court, whose position is shaped by the jurisprudence. In 2019. The Financial Ombudsman twice used the opportunity to request a resolution in order to resolve discrepancies in the jurisprudence of common courts and the Supreme Court. He also filed the first extraordinary complaint to the Supreme Court. The year 2020 of the Ombudsman's activity also means protection of clients' rights by filing actions against banks. The lawsuits were brought against Santander Bank Polska and Bank Handlowy for 
the unjust practice of not lowering the total cost of a consumer credit by the cost of a commission in the case of early repayment. The Financial Spokesman also filed a lawsuit on behalf of the client Idea Bank with the District Court in Warsaw in connection with the bank's unfair market practices introducing it the misguided and prohibited practice of misselling when offering to acquire and offer corporate bonds of GetBack SA. The Ombudsman was the only institution to alert on the case of GetBack and Capital Fund Insurance, the so-called „polisolokaty”.

It should also be pointed out that the limitation of consumer protection will be the combination of administrative proceedings conducted by the Office of Competition and Consumer Protection with bringing an action for the benefit of customers of financial market entities in the Office of Competition and Consumer Protection. This will result in the fact that, in principle, the initiation of administrative proceedings will exclude the possibility of bringing an action for the benefit of clients of financial market entities, which would mean that the consumer would be deprived of possible support from the state body using the judicial path of dispute resolution.

Currently, the tasks of the Financial Ombudsman in Poland include not only protecting the client against financial market entities, but also pointing out supervisory deficiencies. In accordance with Article 17.1.5 of the Act of August 5, 2015 on the handling of complaints by financial market entities and on the Financial Ombudsman, the Ombudsman's tasks include taking action to protect the clients of financial market entities whose interests he represents, and in particular to inform the relevant supervisory authorities and control of the detected irregularities in the functioning of financial market entities. It should be emphasized that the proposed regulation does not contain analogous powers in relation to the President of the Office of Competition and Consumer Protection [Financial Ombudsman, Position of the Advisory Scientific Committee to the Financial Ombudsman in view of the information appearing in the public domain about the intention to liquidate the institution of the Financial Ombudsman and taking over its functions by the President of the Office Office of Competition and Consumer Protection].

\section{Draft law liquidating the Office of the Financial Ombudsman in Poland}

According to the draft act liquidating the Office of the Financial Ombudsman in Poland, the tasks of the President of the Office of Competition and Consumer Protection in the field of protection of the interests of the clients of financial market entities include in particular: examination of applications in individual cases filed as a result of the disregard 
of the client's claims by the financial market entity in the complaint examination procedure, examination of applications concerning the non-performance of activities resulting from the complaint examined in accordance with its content within the indicated time limit, initiation and organization of educational and informational activities in the field of protection of the interests of the clients of financial market entities, as well as providing the Polish Financial Supervision Authority with information on the number and nature of complaints indicating violations of the Act of 19 August 2011. on payment services. Therefore, it should be emphasized that in case of adopting the proposed changes concerning liquidation of the Financial Ombudsman, there will be no entity which will indicate to the supervisory authorities the irregularities in the functioning of financial market entities, which will undoubtedly have a negative impact on the institution of supervision itself.

The draft law also provides for the limitation of the powers of the President of the OCCP in relation to the existing powers of the Financial Ombudsman to issue opinions on draft legal acts concerning the organization and functioning of financial market entities. At present, the Financial Ombudsman has a real impact on the wording of legal acts regulating this area, which the President of OCCP will not have in the new legal status.

The potential conflict of interests in the field of consumer protection should also be noted. There is a wide area in which, in practice, public interest and private interests (of a single consumer) will not overlap (will not be the same). Concentration in one subject of market competition and consumer protection collectively and individually, it may create the potential for activities that may actually either distort competition or "disregard" consumer interests. It can be anticipated that this will lead to a situation in which this body will be obliged to exercise its administrative power while at the same time protecting the private interest of the consumer. The above may not only affect the interests of the consumer, but also of the trader who is a party in the case. At the same time, it should be pointed out that maintaining the principle of financing activities in the scope of protection of individual interests of clients of financial market institutions would also cause a conflict of interests, as according to the proposed legal status, the President of the Office for Competition and Consumer Protection would conduct administrative proceedings against entities that finance its activities.

The issue of conflict of interest should also be raised in the scope of the President of the Office of Competition and Consumer Protection (OCCP) fulfilling the function of a registration body for the activities conducted by the Office subordinate to him. At present, the Financial Ombudsman, on the basis of the current act, i.e. chapter 4 of the Act of 5 
August 2015 on the processing of complaints by financial market entities and on the Financial Ombudsman, is an entity authorized to conduct proceedings for the out-of-court resolution of consumer disputes within the meaning of the Act on the out-of-court resolution of consumer disputes. In accordance with the drafted Article 19.3 of the Act, these competences are to be taken over by the Coordinator acting at the President of the OCCP. It should be pointed out that the Act on out-of-court settlement of consumer disputes grants the President of OCCP the right to keep a register of entities conducting proceedings under the aforementioned Act. Therefore, it seems that in the concept proposed in the draft, the President of UOKiK would be at the same time an entity performing supervision over the proceedings conducted in accordance with the Act 2016 on out-of-court settlement of consumer disputes - with simultaneous competence to conduct them. The above may raise objections as to the implementation by the consumer protection authority of the proper protection of their interests.

The Polish Ministry of Justice expressed a negative opinion on the proposed changes in Polish law, emphasizing also the doubts raised by the change concerning the Financial Education Fund. Currently, in accordance with Article 43a of the Act of August 5, 2015 on the handling of complaints by financial market entities and on the Financial Ombudsman, the Fund's resources are available to the Financial Ombudsman at the request of the Financial Education Council. These funds come, among others, from proceeds from fines indicated in art. $43 \mathrm{~b}$ of the indicated Act. The proposed regulation provides for the establishment of the Financial Education Fund, which will be a state special purpose fund within the meaning of the Act on Public Finance, and will be administered by the President of the Office of Competition and Consumer Protection. The Fund's resources are also to come, among others, from proceeds from fines (draft article 36 of the Act).

It is doubtful that the draft law provides for the possibility of imposing fines by the President of OCCP in Article 41. Thus the proceeds from fines imposed by the President of the OCCP will constitute revenue for the Financial Education Fund, which the President of the OCCP is to administer. It seems that there is a conflict of interest here because the President of UOKiK would combine the role of the disposer of the fund supplied with the proceeds from fines imposed by him, the body supervising proceedings conducted in accordance with the Act on out-of-court settlement of consumer disputes and the body conducting these proceedings.

To sum up, it should be stated that the proposed changes in Poland aimed at combining the tasks of protecting consumers' interests in the financial market within one body raise doubts about their constitutionality. According to Article 76 of the Constitution of the 
Republic of Poland, public authorities protect consumers, users and tenants from activities that threaten their health, privacy and safety and from unfair market practices. The Constitutional Tribunal emphasises in its case law that: "Consumer protection is not a protectionist-paternalistic activity, but aims to safeguard the interests of a weaker market participant whose knowledge and orientation is limited compared to that of a professional partner (seller, service provider). The consumer has a weaker bargaining position, and his specific impairment is due to systemic reasons determined by his market position" (Constitutional Court - K 33/03).

It should be clearly emphasized that the activity of the Financial Ombudsman as an independent entity, which during 5 years of its activity in Poland has developed effective methods of protecting consumer rights, gaining their trust, fulfils the obligation to protect a consumer in a weaker bargaining position indicated in the aforementioned provision of the Basic Law. The Financial Ombudsman, whose aim is to act in the protection of individual consumer rights, ensures full protection of these interests, especially in a clash with financial market institutions stronger than them.

Moreover, the assumption by the President of OCCP of the main tasks of the Financial Ombudsman may result in a collision in the scope of the President of OCCP's previous tasks related to collective interests and individual and public interests. This may result in a significant reduction in the level of consumer protection, contrary to the constitutional principle expressed in Article 76 of the Constitution of the Republic of Poland.

For the European Union and the world is dominated by an institutional model of consumer protection. It should be pointed out that in Europe (not only the EU), the model of subjective separation of bodies carrying out public and legal tasks related to the implementation of consumer protection policy (protection of the collective interests of consumers) and bodies/entities dealing with the collection of individual customer claims and the amicable resolution of disputes is definitely dominant. In the world, the task of protecting the collective interests of consumers is most often carried out by institutions that remain within the government structure. These are ministries, their bodies set up to achieve these objectives or institutions under the direct authority of the Prime Minister, but also independent public institutions. On the other hand, support for individual consumers is provided by non-governmental consumer organisations and out-of-court consumer dispute resolution entities or independent public institutions: Germany, Sweden, the Netherlands, Denmark, France, Norway, Italy, Portugal, the USA, Great Britain, Canada, Ireland, India [Creutzfeldt 2016: 12]. 
The acts of national law governing the functioning of Financial Ombudsmen in the European Union should primarily be consistent with the objective of Directive 2013/91/EU of the European Parliament and of the Council of 21 May 2013 on alternative dispute resolution for consumer disputes and amending Regulation (EC) No 2006/2004 and Directive 2009/22/EC (Directive on consumer ADR). Indeed, recital 53 of that Directive makes it clear that networks of ADR entities such as the financial dispute resolution network 'FIN-NET' in the field of financial services should be strengthened within the Union [European Union, Memorandum of Understanding on a Cross-Border Out of-Court Complaints Network for Financial Services].

The functioning of the Financial Ombudsman, whose legal basis is not directly referred to in European Union law, is a complex legal issue. Whether this model will respond to the needs of the so-called 'New Consumer Order' depends not only on the legislators of individual European Union Member States, but also on the plans of the European Commission itself, as guardian of the Treaties and as the main initiator of regulation in the financial services market. At present, it is difficult to see even an outline of such plans [The Guardian, Whistleblower reveals financial ombudsman service in disarray].

\section{Conclusion}

The acts of national law governing the functioning of Financial Ombudsmen in the European Union should primarily be consistent with the objective of Directive 2013/91/EU of the European Parliament and of the Council of 21 May 2013 on alternative dispute resolution for consumer disputes and amending Regulation (EC) No 2006/2004 and Directive 2009/22/EC (Directive on consumer ADR).

It should be clearly emphasized that the activity of the Financial Ombudsman as an independent entity has developed effective methods of protecting consumer rights, gaining their trust, fulfils the obligation to protect a consumer in a weaker bargaining position indicated in the aforementioned provision of the Basic Law. The Financial Ombudsman, whose aim is to act in the protection of individual consumer rights, ensures full protection of these interests, especially in a clash with financial market institutions stronger than them.

In the European Union, all consumers of financial services should benefit the same level of protection of their rights. The new programme for consumer protection in the European Union recognises the need to consolidate protection policy in order to respond to contemporary problems associated with the progressive digitalisation of financial services. 
The specialised office of the Financial Ombudsman plays a significant role in protecting the legally weaker participants in the financial market. In Ireland, as in Poland, and indeed throughout Europe, there are more and more pitfalls for customers of financial institutions. Insurance and credit agreements are complicated, and more and more provisions appear in the small print that can land clients in trouble for many years. These are the conclusions of the $X X X^{\text {th }}$ Economic Forum in Karpacz in Poland and the debate moderated by the Polish Financial Ombudsman [Debate: Consumer protection on the financial market in the European perspective]. As indicated the starting point should be a reflection on the European Consumer Agenda and the New Consumer Order of 2018, which assumes, among other things, specialised consumer protection depending on the specifics of the market. For, as the Polish Financial Ombudsman pointed out during this forum that we are dealing with the consumer protection problems in the european financial market with regard to both banking services, capital market, insurance and technology and this is the area in which we should expect from the European Union and national law the guarantee of the strong and independent legal status of the Financial Ombudsman in the European Union. 


\section{References}

Bussière M., Camara B., Castellani F., Potier V., Schmidt J.: Transmission des chocs par les banques internationales - le cas de la France

Available at:

https://publications.banque-france.fr/sites/default/files/medias/documents/document-detravail_485_2014.pdf, accessed: $6^{\text {th }}$ February 2021

Creutzfeldt N.: What do we expect from an ombudsman? Narratives of everyday engagement with the informal justice system in Germany and the UK, International Journal of Law in Context, nr 4, 2016

Gerven W.: Bringing (private) laws closer at the European level' (in) Cafaggi, F. et al. (eds), The Institutional Framework of European Private Law, Oxford: Oxford University Press, 2006

Gill C., Williams J., Brennan C., Hirst C.: Models of Alternative Dispute Resolution (ADR): A report for the Legal Ombudsman

Available at: https://eresearch.qmu.ac.uk/handle/20.500.12289/3584, accessed: $6^{\text {th }}$ February 2021

Horbova A., Volodymyr G., Basysta I., Riabchynska O., Hayrapetyan A.: European Models of Functioning and Introduction in Ukraine, Journal of Legal, Ethical and Regulatory Issues, vol. 22, no. 2S, 2019

Howells G., Wilhelmsson T.: EC and US approaches to consumer protection - should the gap be bridged?, Yearbook of European Law, Oxford: Oxford University Press, 1997

Khoury P.: Independent Review of the Ombudsman for Banking Services and Investments, Navigator Report

Available at:

https://www.obsi.ca/en/news-and-publications/resources/PresentationsandSubmissions/2016Independent-Evaluation-Investment-Mandate.pdf, accessed:

Legrand P.: European legal systems are not converging, International and Comparative Law Quarterly, no. 45, 1996

Mania K.: ODR (Online Dispute Resolution) - basic terms, ADR Quarterly, no. 9, 2010

Noked N.: Financial Services Act 2012: A New UK Financial Regulatory Framework

Available at:

https://corpgov.law.harvard.edu/2013/03/24/financial-services-act-2012-a-new-uk-financialregulatory-framework/, accessed: $6^{\text {th }}$ February 2021

Penczar M.: Ochrona konsumenta na integrującym się rynku bankowym w Unii Europejskiej [Consumer protection on the integrating banking market in the European Union], Bank $\mathrm{i}$ Kredyt [Bank and Credit], no. 7, 2007

Rott P.: The protection of consumers interests after the implementation of the EC Injunctions Directive Into German and English Law, Journal of Consumer Policy, vol. 24, 2001

Rutkowska E., Wojtczak D.: Alternatywne sposoby rozwiązywania sporów między bankiem a konsumentem usług bankowych [Alternative ways of solving disputes between a bank and a consumer of banking services], Prawo Bankowe [Banking Law], no. 7/8, 2008

Schulte-Nölke H., Twigg-Flesner C., Ebers M.: EU Consumer Law Compendium, Munich: Sellier. European Law Publishers, 2008

Stone K.: Alternative Dispute Resolution in Encyclopedia of Legal History, Public Law \& Legal Theory Research Paper Series, no. 4, 2001

Thomas D., Frizon F.: Resolving disputes between consumers and financial businesses: Fundamentals for a Financial Ombudsman

Available at:

http://documents1.worldbank.org/curated/en/169791468233091885/pdf/699160v10ESWOPOen OVol10Fundamentals.pdf, accessed:

Wrbka S.: European Consumer Access to Justice Revisited, Cambridge: Cambridge University Press, 2014

\section{Legal Acts}

Act of 5 August 2015 on the handling of complaints by financial market entities and on the Financial Ombudsman (consolidated text Journal of Laws 2019, item 2276, as amended).

Act of 16 February 2007 on Competition and Consumer Protection (consolidated text Journal of Laws 2020, item 1076, as amended)

Directive 93/13/EEC of 5 April 1993 on unfair terms in consumer contracts 
Directive 2013/91/EU of the European Parliament and of the Council of 21 May 2013 on alternative dispute resolution for consumer disputes and amending Regulation (EC) No 2006/2004 and Directive 2009/22/EC (Directive on consumer ADR)

Financial Services Act 2012, UK Public General Acts (2012, c. 21)

Regulation (EU) 2017/2394 of the European Parliament and of the Council of 12 December 2017 on cooperation between national authorities responsible for the enforcement of consumer protection laws and repealing Regulation (EC) No 2006/2004

\section{Other Official Documents}

European Commission, Proposal for a Regulation of the European Parliament and of the Council Establishing a European Small Claims Procedure COM (2005), 87 final

\section{Internet Resources}

Debate: Consumer protection on the financial market in the European perspective Available at: https://rf.gov.pl/2021/09/09/debata-ochrona-konsumenta-na-rynku-finansowym-wperspektywie-europejskiej-rzecznik-finansowy-na-xxx-forum-ekonomicznym-w-karpaczu/, accessed: $15^{\text {th }}$ September 2021

Financial Ombudsman in Poland

Available at: https://www.knf.gov.pl/en/CONSUMERS/Customer_Protection_on_Financial_Services_Mark et/Financial_Ombudsman, accessed: $6^{\text {th }}$ February 2021

FIN-NET members in Poland

Available at:

https://ec.europa.eu/info/business-economy-euro/banking-and-finance/consumer-financeand-payments/retail-financial-services/financial-dispute-resolution-network-fin-net/fin-netnetwork/members-fin-net-country/fin-net-members-poland_en accessed: $6^{\text {th }}$ February 2021

Financial Ombudsman, Position of the Advisory Scientific Committee to the Financial Ombudsman in view of the information appearing in the public domain about the intention to liquidate the institution of the Financial Ombudsman and taking over its functions by the President of the Office Office of Competition and Consumer Protection

Available at:

https://rf.gov.pl/wp-content/uploads/2020/09/Stanowisko-DKN.pdf, accessed: $6^{\text {th }}$ February 2021

Memorandum of Understanding on a Cross-Border Out of Court Complaints Network for Financial Services

Available at:

https://ec.europa.eu/info/sites/info/files/memorandum-of-understanding_en.pdf, accessed $6^{\text {th }}$ February 2021

Polish Financial Ombudsman's International e-Conference Financial Markets and Consumer Protection

Available at:

https://rf.gov.pl/2020/11/30/polish-financial-ombudsmans-international-e-conferencefinancial-markets-and-consumer-protection/, accessed: $6^{\text {th }}$ February 2021

Whistleblower reveals financial ombudsman service in disarray

Available at:

https://www.theguardian.com/business/2019/dec/14/whistleblower-reveals-financial ombudsman-service-in-disarray, accessed: $6^{\text {th }}$ February 2021 